\title{
厚板レーザー溶接技術の新展開
}

石出 孝, 坪田 秀峰, 名山 理介, 下楠 善昭*, 福本 清治*

三菱重工業 (株) 高砂研究所 ( $\% 676-8686$ 兵庫県高砂市荒井町新浜2-1-1)

*三菱重工業(株) 神戸造船所（テ $652-8585$ 兵庫県神戸市兵庫区和田崎町1-1-1）

\section{Recent Evolution of High Power Laser Welding in Heavy Components}

\author{
Takashi ISHIDE, Shuho TSUBOTA, Michisuke NAYAMA, \\ Yoshiaki SHIMOKUSU,* and Kiyoharu FUKUMOTO* \\ Takasago R\&D Center, Mitsubishi Heavy Industries, Ltd., 2-1-1 Shinhama, Arai-cho, Takasago, Hyogo 676-8686 \\ * Kobe Shipyard \& Machinery Works, Mitsubishi Heavy Industries, Ltd., 1-1-1 Wadasaki-cho, Hyogo-ku, Kobe, Hyogo 652-8585
}

(Received June 15, 2000)

\begin{abstract}
This paper reviews techniques to apply the laser welding to heavy components. Especially high power $\mathrm{CO}_{2}$ laser applications in this area which include ship building and bridge building industry and high power YAG laser welding in the nuclear power plants are dealt with. In addition, future lasers for processing in heavy components are discussed.
\end{abstract}

Key Words: Heavy components, Laser welding, High power YAG laser, Multi-pass laser welding

1. はじめに

厚板分野でのレーザー溶接ではこれまで発振器出力の 高い $\mathrm{CO}_{2}$ レーザーによる検討が精力的に成されてきたもの の, その実用化は発振器自体のイニシャルコストの高さ, ポ ロシティに起因する溶接品質面での不安, ビーム品質の安 定性, 長距離のビーム伝送性等の難しさから特定分野に限 られてきた。これに対し, 最近, YAGレーザーの開発及び その高出力化は著しく, 1パスで $10 \mathrm{~mm}$ 以上板厚の製品の 溶接が可能となりつつある. 現状の高出力YAGレーザー は, $\mathrm{CO}_{2}$ レーザー程ビーム品質が良くないことから, 高速領 域での溶込み能力は劣るもののファイバ伝送が可能なこ とから複雑大型形状部材の溶接に適し, $\mathrm{CO}_{2}$ レーザーに比 ベ, ビーム伝送後のビーム強度分布が安定している．また， ピーク出力が定格出力の 2 3 倍得られることから, $\mathrm{CO}_{2}$ レーザーの同一定格出力の発振器と比べ, 溶込み能力が高 く, 厚板溶接に有利である. プロセス面でも深溶込みが得

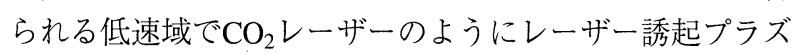
マによるビーム吸収の影響1)を受けないことから実施工で のプラズマ制御溶接が不要で溶接品質が安定する.

以上のように, 厚板分野での溶接を考えた場合, YAG レーザーは $\mathrm{CO}_{2}$ レーザーに比べ様々な優位性を持つことか ら, 今後その実用化は益々増加してゆくと考えられる。本 報では最近の厚板分野での高出力レーザー溶接の適用状 況を述べるとともに, $10 \mathrm{~kW}$ 級YAGレーザーの溶接特性と その実用化について示す. さらに, 今後の厚板溶接の展開
を考える。

\section{2. 高出カレーザー溶接の適用状況}

厚板製品の溶接が要求される産業分野として, 鉄鋼, 造 船, 橋梁, 原子力, 原動機分野等があげられる。この各分野 での適用状況について述べる，鉄鋼分野での高出力レー ザーの適用は最も早くから行われてきており, 1980年代に 熱延・冷延鋼板の連続コイル板継ぎ溶接ラインへの実用 が開始されたものの ${ }^{2)}$, レザー出力はその当時の出力の 制限, 安定性より $10 \mathrm{~kW}$ クスに止まっていた。しかし, 1995年に $25 \mathrm{~kW}$ の $\mathrm{CO}_{2}$ レーザーが溶接鋼管ラインに導入さ れ, 板厚 $16 \mathrm{~mm}$ まで高速溶接が高周波加熱とアプセットに よる複合プロセスとして実用化されている3). さらに, 最 近では, 熱延工程中の板継ぎ溶接に 2 台の $45 \mathrm{~kW}$ 級 $\mathrm{CO}_{2}$ レー ザーが使われている例も報告されている4). 造船分野での 実用は欧州での客船, フェリー等におけるサンドイッチパ ネルの溶接があげられる。ドイツのMeyer Werftでは同強 度で重量軽減が図れ, 定形鋼板のモジュール化した部材の 溶接になることを利用したコスト低減効果を狙い, Fig.1に 示すようなサンドイッチパネル構造を $12 \mathrm{~kW}$ と $14 \mathrm{~kW} の \mathrm{CO}_{2}$ レーザーを用い溶接構造化し, 客船の船倉隔壁やデッキに 採用している5)。 また, デンマーク Odense Steel Shipyardで もコンテナ船のサブ材スティフナー部の隅肉溶接を $12 \mathrm{~kW}$ の $\mathrm{CO}_{2}$ レーザーにより行っている.

橋梁分野ではFig.2に示すように道路橋床版の $45 \mathrm{~kW} \mathrm{CO}_{2}$ 


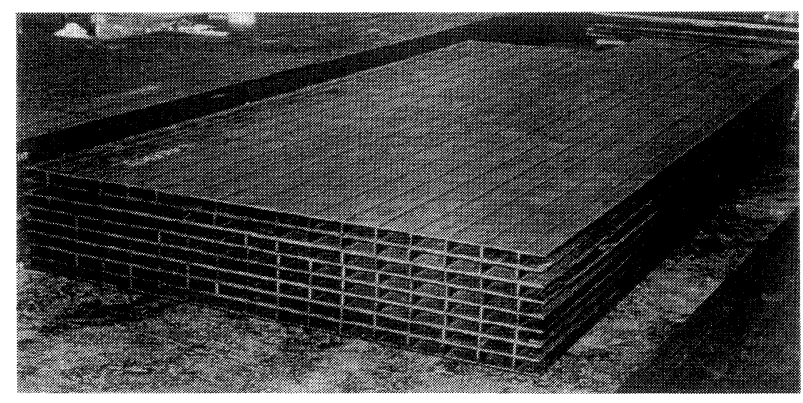

Fig.1 Laser welded sandwich panels.

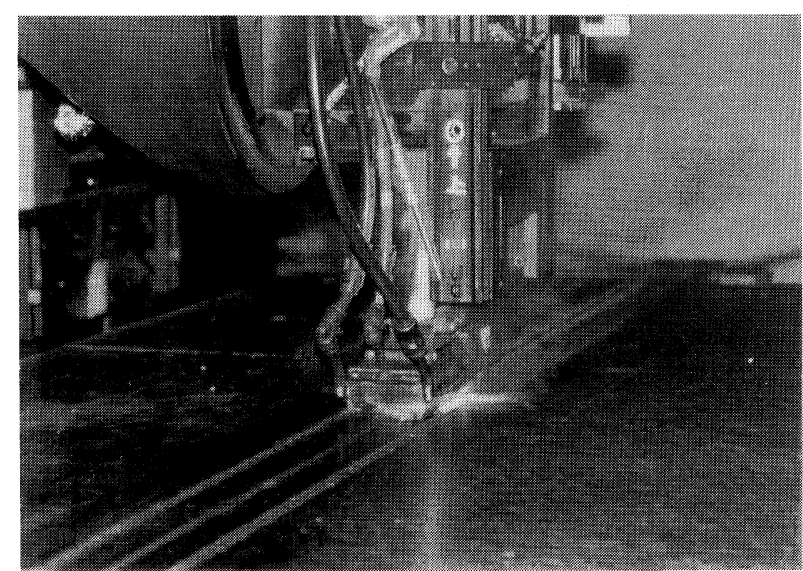

Fig.2 Laser lap welding of bottom plate for highway bridge.

レーザーによる溶接が検討されており, 継手強度, 疲労強 度等の評価が実物モデルにて行われている6).

以上の実用化, あるいは検討例はいずれも高出力が得ら れる $\mathrm{CO}_{2}$ レーザーの溶接速度が $1 \mathrm{~m} / \mathrm{min}$ 以上の比較的高速領

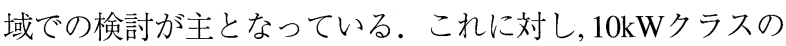
YAGレーザーによる厚板溶接への適用検討結果を以下に 亦す.

\section{3. 高出カYAGレーザーの溶込み特性}

Fig.3に10kW級YAGレーザーによる連続発振 (以後CW)

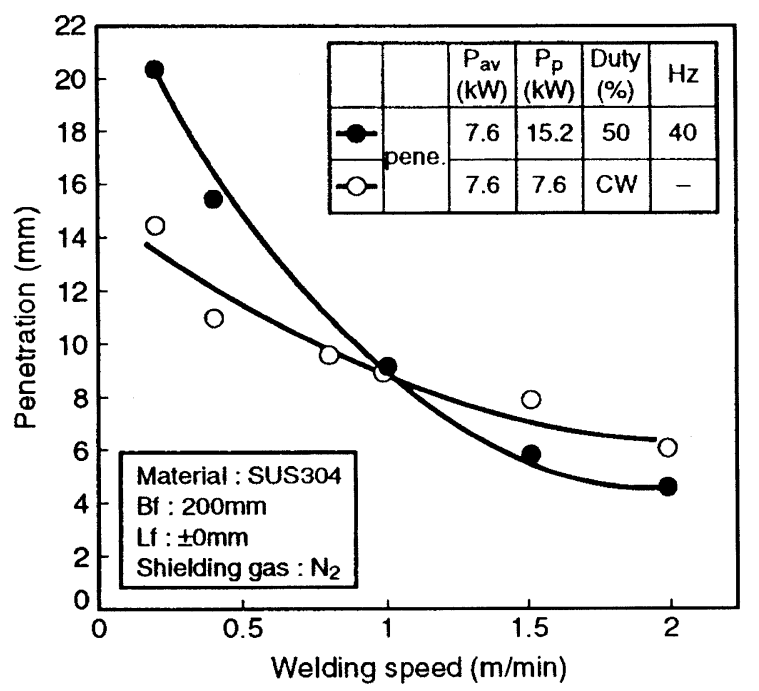

Fig.3 High power YAG laser penetration characteristic.
とパルス発振 (モデュレーションによるパルス化, 以後PW) の溶込み特性を示す。この溶接では, SI型のコア径 $0.8 \mathrm{~mm}$ の光ファイバを利用するとともに, 光学系は $B f($ バック フォーカス $)=200 \mathrm{~mm}$, レンズロ径 $60 \mathrm{~mm}$ の集光系を用い た. Fig.4に示す $10 \mathrm{~kW}$ 以上の $\mathrm{CO}_{2}$ レーザーでの溶込み特性 では溶接速度が低下するにつれ，レーザー誘起プラズマの ビーム吸収による溶达み深さの減少が著しく7), プラズマ 制御による溶接が必要となる。これに対し, YAGレーザー では低速になるにつれ溶込み深さは増大し, レーザー誘起 プラズマの影響は生じていない.このため溶接出力7.6kW, 溶接速度 $0.2 \mathrm{~m} / \mathrm{min}$ の低速でPWにて $21 \mathrm{~mm}$ の溶込み深さが 得られるとともにCWでも $15 \mathrm{~mm}$ の溶达み深さが得られて いる。一方, 高速域ではCWがPWに比べ深い溶込みが得ら れている.これはCWでは定常的にキーホールが形成され ているのに対し,PWでは1パルス毎にキーホールを再形成 するため高速になるにつれ,十分深いキーホールが形成さ れにくくなっているものと考えられる.

このようにYAGレーザーは $\mathrm{CO}_{2}$ レーザーに比ベ, レー ザー誘起プラズマの影響を受けないものの, 波長が短い分 溶接部に発生するヒュームによるビームの散乱の影響を 受けやすい8). Fig.5は各波長のレーザービームをプローブ レーザーとして溶接部直上に照射した際の透過率を示し たもので, $\mathrm{CO}_{2}$ レーザーでは殆どビーム損失がなく, YAG, He-Neレーザーと短波長側のビームになるにつれ, ビーム 透過損失が大きくなっていくことが分かる.

Fig.6にレンズ系バックフォーカス $(B f)$ の溶込みへの影響 を示す。ここでの比較はレンズ口径を一定として $B f$ を変化 させた際の溶込みを比較している。従って, Bfが長くなる と, 焦点深度, 集光スポット径ともに大きくなっている. この結果より, 高速溶接では集光スポット径の小さい $B f=$

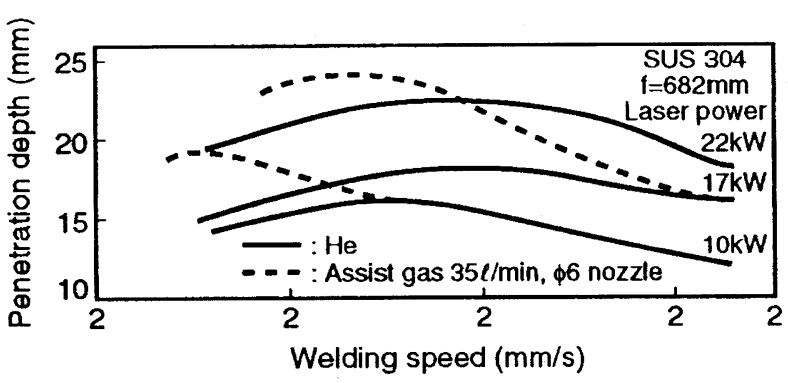

Fig.4 High power $\mathrm{CO}_{2}$ laser penetration characteristic.

C.W. $2.5 \mathrm{~kW}$

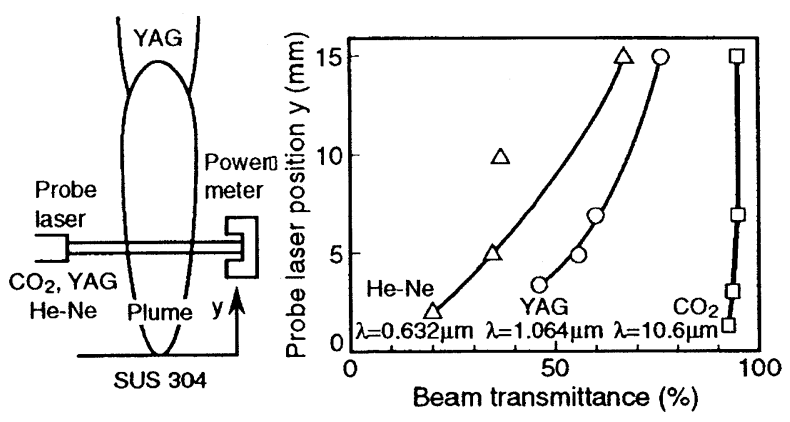

Fig.5 Effect of welding fume on beam transmission. 


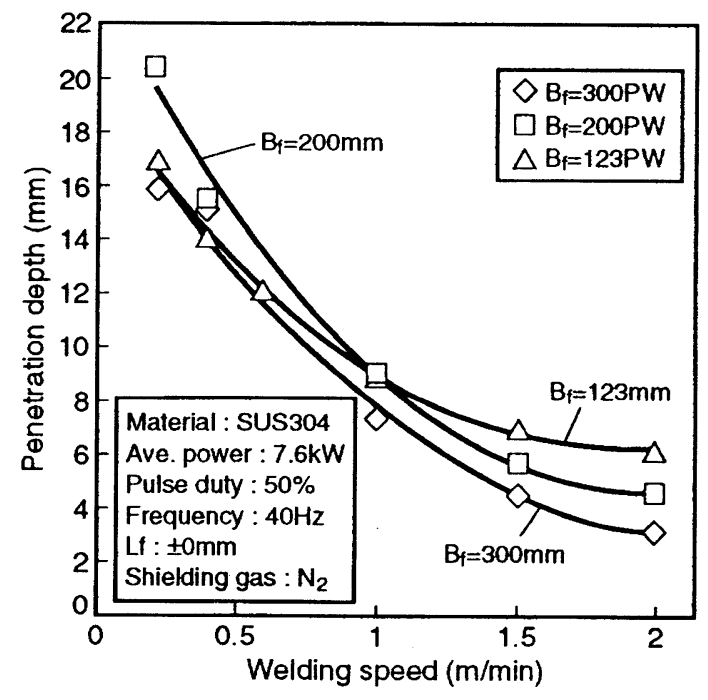

Fig.6 Effect of focal length on penetration depth.

$123 \mathrm{~mm}$ の溶込みが深くなるものの, 低速域では $B f=200 \mathrm{~mm}$ での溶込みが最も深くなる。一方, $B f=300 \mathrm{~mm}$ は, 作業性 は良いが, 溶込み深さは全般的に浅くなる. 以上より, 高 出力YAGレーザー溶接での深溶込み化には, $B f=200 \mathrm{~mm}$ 有効と判断される. 以後, この出力域での深溶込み化に適 した $B f=200 \mathrm{~mm}$ を溶接試験に用いている.

\section{4. パルス条件検討による深溶込み化}

\section{1 パルス周波数の影響}

Fig.7に平圴出) $4.5 \mathrm{~kW}$, バル人デューテイ $50 \%$ (パルスオ ンタイムとオフタイムが同じ), 溶接速度 $0.4 \mathrm{~m} / \mathrm{min}$ でパルス 周波数を $40 \mathrm{~Hz}$ から $200 \mathrm{~Hz}$ まで変化させた際の溶込み形状を 示す。これょりパルス周波数の低下とともに溶込み深さ が増大し, ビード幅が低減する結果が得られた。これはパ ルス周波数の低下とともにパルスオンタイムが長くなり， 1パルスでの溶込み深さが増大するためと考えられる，パ ルス周波数 $40 \mathrm{~Hz}$ 以下の条件は発振器からの制約より実現 することが難しいことから, 以後 $40 \mathrm{~Hz}$ 以上での検討をおこ

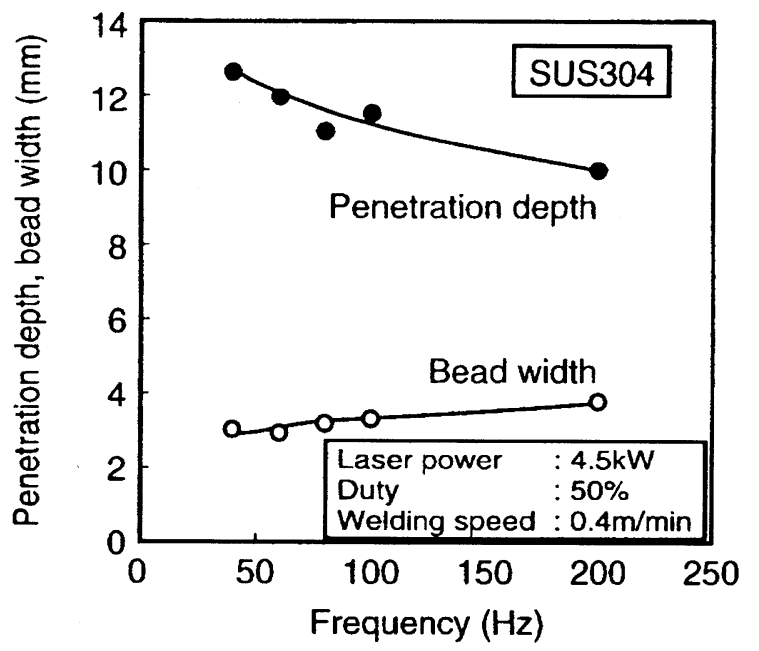

Fig.7 Relationship between pulse frequency and penetration shape.

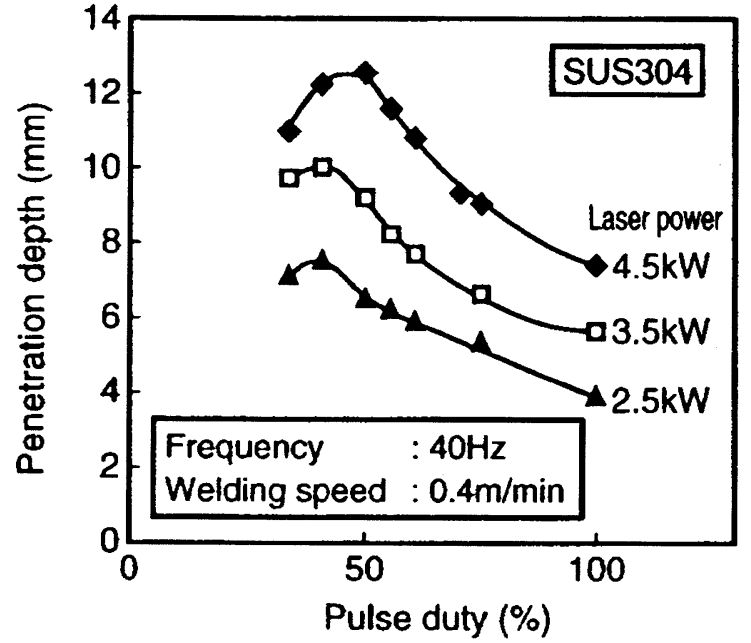

Fig.8 Relationship between pulse duty and penetration depth.

なっている。

\section{2 パルスデューティの影響}

Fig.8に平均出力 $2.5,3.5,4.5 \mathrm{~kW}$ におけるパルスデュー ティの溶込み深さへの影響を示す。いずれの出力におい てもデューティが小さくなる(ピーク出力が増大する)につ れて溶込み深さが増大する。一方, デューティが50\%以下 となるとそれぞれ飽和傾向を示し,さらにデューティが低 下すると溶込み深さは減少している。この原因を考える ため, 高速度ビデオにより溶接時のレーザープルームの発 生状沙を各々のデューティで観察した。その結果をFig.9 に示す。同図にはレーザーの発振波形とその各々の時間 でのプルーム挙動を示している。 その結果, 1パルス間で3 種類のプルームの挙動が観察された。その各々を時間経 過の順にRegion I, II, III とすると

Region I：パルス発振波形の先頭部であり,レーザープ

$$
\text { ルーム発生が著しい時間領域 }
$$

Region II ：レーザープルームの発生が殆ど見られない時 間領域

Region III：プルームが再度発生し, 発生量の変動が激し い時間領域

が存在することが分かる。これよりRegion Iでは溶达みが 急激に増大し, 大きなレーザープルームが発生し, Region II ではRegion I程ではないものの溶込みは増大していると考 えられる. Region IIIではキーホールが不安定になり,キー ホール上方に流れ込む溶融金属にビームが照射され, 再度 大きなプルームが発生すると考えられる99. 以上よりパル スデューティが40\%より低下すると溶込み深さが減少して いるのは,パルスオンタイムが短くなり溶込み深さが飽和 していないためと考えられる。一方,パルスデューティを 大きくするとピーク出力も低下し, Region IIIの領域が多く なり, 平均出力が同じでもレーザービームのエネルギーが 溶込み深さ増大に十分寄与していないものと考えられ る. 以上の結果より, 各溶接速度, 溶接出力に対し, 深溶込 みが有効に得られるパルスデューティが存在することが 分かる。 


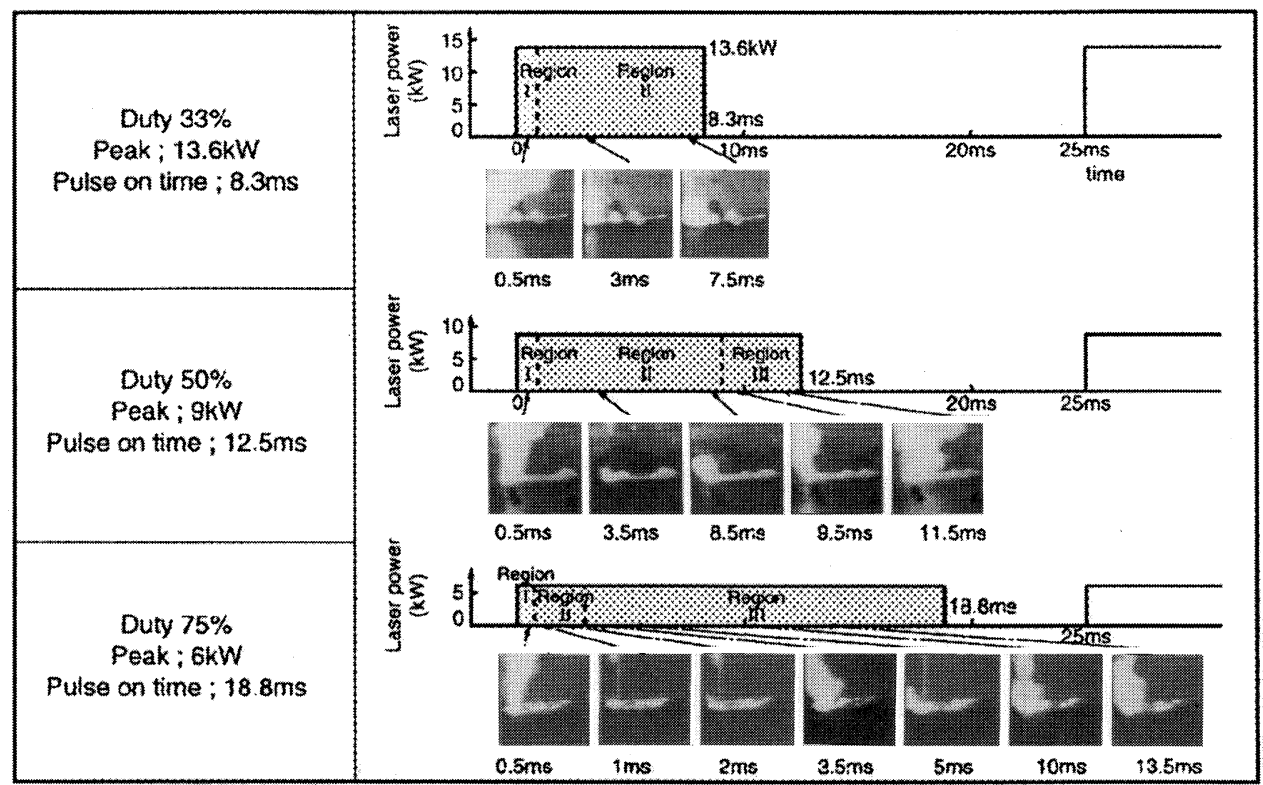

Fig.9 Plume conditions in each pulse condition $(4.5 \mathrm{~kW}, 40 \mathrm{~Hz}, 0.4 \mathrm{~m} / \mathrm{min})$.

\section{5. ステンレス鋼容器へのYAGレーザー溶接の適用}

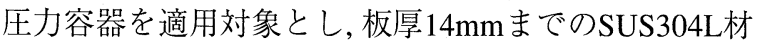
での適正溶接条件範囲について裏波ビード形状, ビード表 面形状に着目し,焦点ぼかし量 $(L f)$ と溶接速度に関し, 貫通 溶接が可能な適正施工範囲を調べた結果をFig.10に示す. この施工条件については発電用機器の溶接施工法確認試 験に準じ, PT, RT, 硬さ, 断面マクロ・ミクロ,引張・曲げ 試験, 腐食試験を実施し，いずれにおいても良好な試験結 果を確認している。

Fig.11には再処理プラント向けステンレス鋼容器 $(\phi 1.4 \mathrm{~m}$ $\times \mathrm{H} 1.8 \mathrm{~m} \times 6 \mathrm{mmt}) へ の$ 実用化状況を示す.このステンレス 鋼容器は平板をロール曲げした後, 治工具にて固定し, 長 手溶接が行われ, 溶接終了後, 浸透探傷試験, 放射線透過試 験を行い, 良好な結果を得ている.

\section{6. 今後の厚板溶接の展開}

溶接に用いるツールとしてのYAGレーザー発振器の開 発の進展には著しいものがあり, NEDOのフォトン計測 · 加工技術プロジェクトでは平成13年を目指し, $10 \mathrm{~kW}$ 級LD 励起YAGレーザーの開発が進められており, 現在すでに

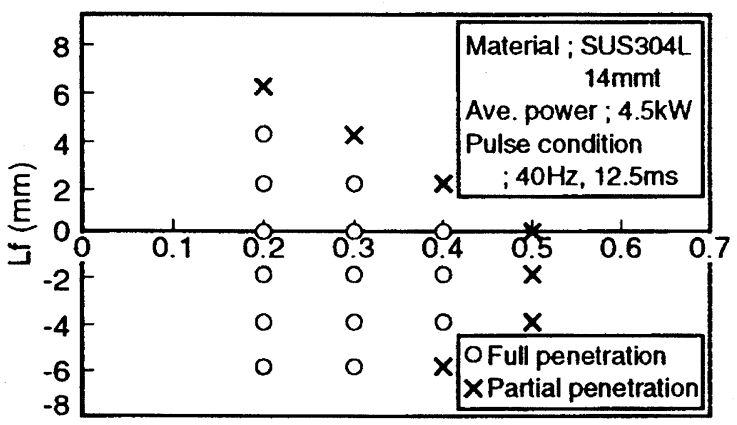

Welding speed $(\mathrm{m} / \mathrm{min})$

Fig.10 Proper full-penetration welding conditions.

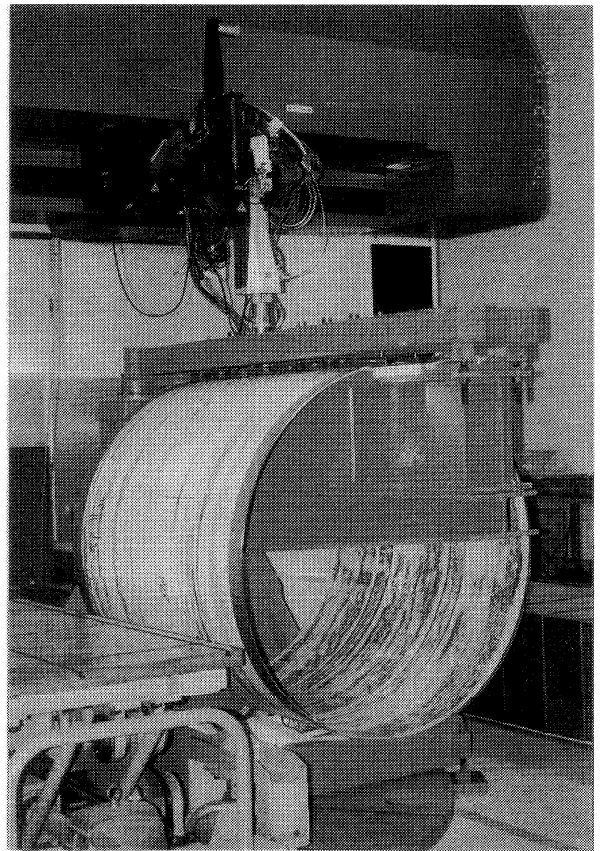

Fig.11 Welding condition in stainless steel tank.

3kW級のLD励起YAGレーザーが販売されている。さらに LDによる直接加工についても, 溶接を対象とした試験が試 みられ ${ }^{10)}$, ランプ励起のYAGレーザーの効率3\%に対し, LD 励起YAGレーザーが $15 \%, \mathrm{LD}$ は $50 \%$ 近い効率が期待され， 現状6kWクラスのものまで開発されている．米国のPrecision Laser Machining プロジェクトやドイツでのビーム品質 の向上を狙った加工用LD開発のプロジェクトのスタート により,さらにLD自体の価格の低下が進み, 将来LDによる 直接溶接機が出現するのも間近となりつつある.

また, プロセス面では厚板を対象とした超狭開先の溶接 が検討されていくものと考えられる。これはFig.12にYAG レーザーによるマルチパス溶接例を示すが, 今後, さらに 開先幅を小さくした高効率な厚板溶接プロセスが開発さ 


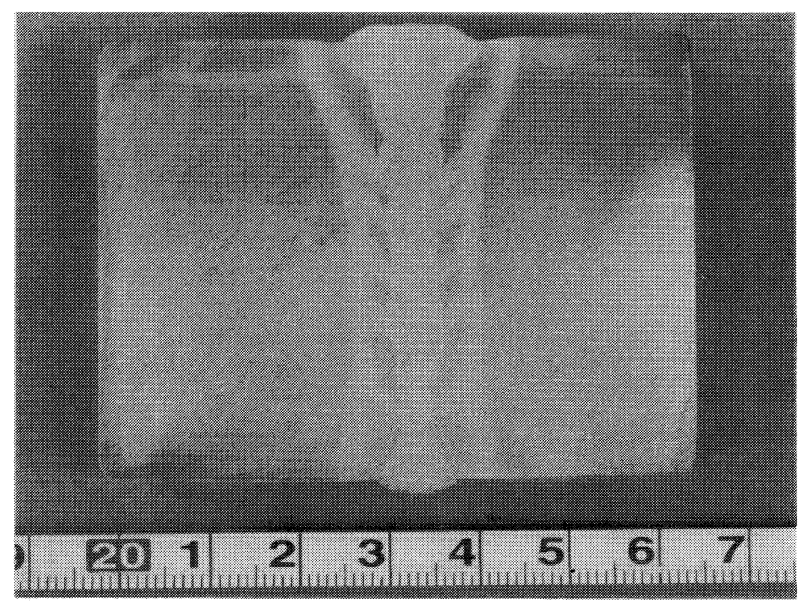

Fig.12 Multi-pass welding by YAG laser (48 mmt).

れていくものと考えられる.いずれにしても, 発振器メー カとユーザの両者の開発がお互いの利益を引き出す方向 に進むことがこの方面での技術進展の牽引となることに
間違いないと考えられる。

\section{参考文献}

1) M. Nayama, T. Ishide, M. Mega, S. Aoki, and T. Koguchi: Proc. of CISFFEL6 (1998) 137.

2) H. Sasaki: Transaction of the iron and steel institute of Japan, $\mathbf{2 b}$ (1986) No.5, 491.

3) M. Ono, T. Shiozaki, M. Ohmura, H. Nagahama, and K. Kohno: Proc. of ECLAT'96 (1996) 115.

4) K. Minamida: Proc. of SPIE High-Power Laser in Manufacturing 3888 (1999) 533.

5) F. Roland: FOCAL. SPO. WPO, March (1995)

6）北側 彰一, 福田 直晃, 武田 慎之助, 大澤 守彦, 声田 英史, 石原 照久, 金吉 正勝, 福本和弘：日立造船技報 60 (1999) No.3, 56.

7) T. Ishide, S. Shono, T. Ohmae, H. Yoshida, and A. Shimmi: Proc. of LAMP'87 (1987) 187.

8) 小島 庸光, 池田 卓郎, 宮本勇, 坪田秀峰, 石出 孝, 長島 是: 溶 接学会全国大会講演概要 No.66 (Spring, 2000) 56.

9) T. Kojima, E. Ohmura, I. Miyamoto, T. Nagashima, and T. Ishide: Proc. of ICALEO '98 (1998) 187.

10) F. Bachmann: SPIE-Proceedings 3888 (1999) 67. 